\title{
Focused Corrective Feedback and Negotiation of Meaning: Students' Written Language Accuracy and Their Perception.
}

\author{
Flora \\ English Department \\ Faculty of Education \\ Lampung University \\ Lampung 35141, Indonesia
}

\begin{abstract}
This study is designed to investigate :1) students' written language accuracy, 2) effectiveness of teacher's indirect corrective feedback in enhancing students' written language accuracy, 3) effectiveness of negotiation of meaning during direct peer corrective feedback, and 4) the students' perception after the implementation of focused corrective feedback and negotiation of meaning. In enhancing students' written language accuracy, indirect corrective feedback in the form of codes, and peer direct corrective feedback in the form of explanation were applied to 24 students of English Education Faculty (FKIP) of the University of Lampung who took Pre-intermediate writing class. The design was descriptive quantitative. The results demonstrate that ; (1) language accruracy on grammar is considered low but not on vocabulary and spelling, 2) indirect corrective feedback works well only if the students' have prior linguistic ability, 3) direct corrective feedback works well because peer (s) did negotiation of meaning in forms of clarification, and 4) students have various response during the corrective feedback. The finding was discussed on the basis of relevant theories.
\end{abstract}

Keywords: Focused corrective feedback, indirect and direct corective feedback, negotiation of meaning, written language accuracy, and perception.

\section{Introduction}

In writing, language accuracy is badly needed. It refers to the ability to use the language correctly (Polard , 2008; Housen, A., Kuiken, F., and Vedder, I. , 2012; Ahangari, S., and Barghi, A. H. (2012). However, most of foreign language learners still make some mistakes in the target language (Flora, 2016, 2019, 2020). In relation to this, several empirical studies have proved the effectiveness of Corrective Feedback (CF) applying various techniques in writing. For example, Baleghizadeh and Masoun, (2013) gave guidance sheet to the students whether their works have already fulfiled the qualiy of writing. Their focus is on the learners' self-efficacy. By giving feedback in the form of codes, Bitchener, Young and Cameron (2005) state that the learners are able to improve students' writing quality. Cahyono and Amrina (2016) applied peer corrective feedback. In this study, the peer correctors were asked to write on a tick "yes", "no" or "not sure" for the topic sentence, supporting sentences, and content. In addion, the correctors were also asked to put a circle on "wrong" or "not sure" for grammar and mechanics. Tan and Manochphinyo's (2017) study led to the deduction that these two types of feedback are effective for improving learners' grammar, such as subject-verb agreement and articles. By paying attention to corrective feedback in the form of codes, students' accuracy in their sentences get better (Kurzer and Kendon,2017). All these studies belong to indirect corrective feedback.

In relation to corrective fedback, Heaton (1991) suggests the minimum criteria of writing for intermediate level, namely: grammar, vocabulary and spelling or linguistic knowledge (Saadian, H., and Bagheri, M. S. ,2014). In conclusion, accuracy in writing could be defined as the correctness of the students' writing performance related to the linguistic knowledge. Ellis (2009) perceives corrective feedback as something that must be examined deeper. For instance, what needs to be corrected, how to correct it, and to what extent the correction matters. In addition, Sheen and Ellis (2011), declared that Focused corrective feedback is potentially more effective than unfocused corrective feedback. In other words, if the teacher corrects all components of writing as suggested by Jacobs (1981) and Brown (2001), it can make the beginner learners frustrated.

Considering the statement above (Saadian, H., and Bagheri, M. S. , 2014; Sheen, Y and Ellis, R (2011), in this present study, the corrective beedback will limit on 3 aspects, namely; grammar, vocabulary and spelling. Hinkel (2011) stated that the term correct refers to accurate grammatical usage as prescribed by academic grammars of the language. In relation to this, Javed, et al (2013), Saadian \& Bagheri (2014), and Bae ( 2001) declared that without having adequate competency in grammar, it is unlikely that learners can produce writing with good quality and text length reasonable enough to communicate ideas. The next is vocabulary. Vocabulary is the heart of language skills. Therefore, vocabulary knowledge has been viewed as a prior ability that has to be mastered to increase other language abilities (Alqahtani, 2015; Susanto, 2017; Dakhi, 2019). Having a limited vocabulary in a second language impedes successful communication. By this way, the acquisition of vocabulary is essential for 
successful second language use and plays an important role in the formation of complete spoken and written texts. The third, is spelling. Due to this, some experts (Bolton, F. \& D, Snowball , 1993; Cook, V., 2010; Kreiner, D. S., et al, 2014 ) claimed that a paper that has a lot of spelling errors probably would hinder the reader to follow his thoughts of ideas and it shows the quality of the writer that he has low cognitive ability.

Pica (1994) declared that during negotiation of meaning, usually the learners modify input and it is possible to develop the quality of the target language. To strengthen this idea, Farangis (2013),confirms that negotiation of meaning can help the students improve their second language acquisition. In line with this idea, Ko, et al (2003) stated that the learner did negotiation of meaning in form of clarification request if he does not know how to say someting in English. In addtion, Moussa, et all (2019) stated that Feedback happens during the negotiation of meaning. They claim that there is improvement of students' writing quality after receiving feedback from their classmates.

While on the subject of direct and indirect corrective feedback, Tan and Manochphinyo's (2017) study led to the deduction that these two types of feedback are effective for improving learners' grammar, such as subject-verb agreement and articles. Through the repetition of corrective feedback in the form of codes, students' accuracy in their sentences get better than the accuracy of those who are engaged in self-correction (Kurzer and Kendon, 2017). Cahyono and Amrina(2016), who carried out a study on the students of the University of Malang-Indonesia, discovered that PCF is superior to self-correction in the sphere of learners' writing quality. Exploring the students' perception is benefecial because it can give contribution about the effectiveness of learning model (Tavakoli, 2009: Awwad, 2019). In relation to this, Ahmad, at.al, ( 2017) stated that one of factors that affected students' academic performance is teaching strategy. Therefore, it is important to ensure that the teaching strategy applied by the teacher in the classroom can facilitate the students to learn well and can meet what is needed by the students.

In this study, the teacher applied indirect corrective feedback, that is only by giving the code (gr) for grammar,(vc) for vocabulary, and and (sp) for spelling on students' works. By paying attention to the code(s), the students are expected to correct them using their prior linguistic knowledge. While direct corrective feedback, they were instructed to ask help from their peer(s) for those they do not understand. In this time, negotiation of meaning will occur. This is done due to the statement that learner feel more free if they did intraction among themselves ( Pica, 1985; Flora, 2016) and the students can get input from his own output (Swain and Lapkin 's, 1995). Based on the statements elaborated by Ahmad, at.al, (2017), Tavakoli (2009), and Awwad, (2019), in this study, the researcher feels that it is also important to know about the quality of teaching and learning by investigating the students' perception toward the teaching strategy applied in this study. Thus, the research problems are as follows:

1. How is writing accuracy of the first year students of the Faculty of English Education Study Program -Lampung University?

2. How effective is teacher's indirect corrective feedback in enhancing students' writing accuracy?

3. How effective is negotiation of meaning during direct peer corrective feedback?

4. How is the students' perception after the learning process?

\section{Methodology.}

\section{Participants}

The subject of this study is the first year students of the Faculty of English Education Study Program who who took Pre-intermediate writing class (24 students) in academic 2019/2020. In the future, they are prepared to be English teachers. Therefore, linguistic accuracy is badly neeeded.

\section{Instruments}

The istrument of this study is essay writing. They were asked to write at least 200 words length based on the topic given ( Why do people have breakfast?). To have in-debth information about the learning process, open-ended questionaire was also applied.

\section{Procedures of Data analysis}

1. The drafts of students' writing were read by qualified English teachers. Those belong to incorrect grammar, vocabulary and spelling were coded; gr (grammar), vc (vocabulary), and sp (spelling).

2. To know the students' accuracy on each linguistic aspect, the following formula was used;

Grammar $=\frac{\text { Number of error free T-Units }}{\text { Total target T-Units produced }} \times 100$

Vocabulary score $=\frac{\text { Number of correct vocabulary produced }}{\text { target words length }} \times 100$

Spelling score $=\frac{\text { Number of correct words spelling prduced }}{\text { target words length }} \times 100$ 
1. The drafts were then given back to the students and they were instructed to revise those mistakes individually. This was done based on Trabelsi's finding (2018) that the teachers use of the indirect feedback in order to make students think about their mistakes.

2. All incorrect revisions were given back to each student. In this time, they were instructed to ask for help from their peer (s).

3. Open-ended questionaire was given to each student. It was done in order to know their perception during the learning process. The researchers will guide the students to answer the open-ended questions.

\begin{tabular}{|l|l|l|l|}
\hline No & Categories & Question & Answer \\
\hline 1 & Level of Difficulty & $\begin{array}{l}\text { 1. What do you think about this learning } \\
\text { activity? ( when you did self - revision). Is } \\
\text { it easy? } \\
\text { Why? / What is the evident? }\end{array}$ & \\
\hline 2 & Degree of Stress & $\begin{array}{l}\text { 2. What do you think about this learning } \\
\text { activity? ( when you do peer correction } \\
\text { during negotiation of meaning ). Is it easy? } \\
\text { Why? / What is the evident? }\end{array}$ & $\begin{array}{l}\text { 3. How do you feel when you when you are } \\
\text { correcting the mistakes by your self? }\end{array}$ \\
\hline 3 & Interest and motivation & $\begin{array}{l}\text { 4. How do you feel when your friends give } \\
\text { you feebback? }\end{array}$ & $\begin{array}{l}\text { 5. What do you think of this learning } \\
\text { process, is it interesting or not?) } \\
\text { (Why? / What is the evident?) }\end{array}$ \\
\hline & $\begin{array}{l}\text { 6. Does corrective feed back motivate you } \\
\text { tomake more effort and to think harder? }\end{array}$ & \\
\hline
\end{tabular}

Result

The result of this study will be reported based on the reseach questions elaborated before.

1.Students' written language accuracy (Grammar, vocabulary, and spelling)

Having read and calculated the T-units and number of vocabulary of students' draft, those belong to incorrect linguistic were coded and tabulated (table 1)

Table 1. Students' Writing Accuarcy.

\begin{tabular}{|c|c|c|c|c|c|c|c|c|c|c|c|c|c|c|c|c|}
\hline \multirow[t]{2}{*}{ NO } & \multirow[t]{2}{*}{ CODB } & \multicolumn{5}{|c|}{ GRAMMAR/T-UNIT } & \multicolumn{5}{|l|}{ VC } & \multicolumn{2}{|l|}{ SP } & \multirow[b]{2}{*}{$\%$} & \multirow[b]{2}{*}{ CR } & \multirow[b]{2}{*}{$\%$} \\
\hline & & $\mathbf{T}$ & INC & $\%$ & $\mathbf{C R}$ & $\%$ & $\mathbf{T}$ & INC & $\mathbf{\%}$ & $\mathbf{C R}$ & $\mathbf{\%}$ & $\mathbf{T}$ & INC & & & \\
\hline 1 & AIs & 34 & 11 & 32 & 23 & 67 & 387 & 2 & 0,005 & 385 & 0,995 & 387 & 0 & 0 & 387 & 100 \\
\hline 2 & DED & 35 & 21 & 60 & 14 & 40 & 284 & 6 & 0,021 & 278 & 0,979 & 284 & 1 & 0,004 & 283 & 0,996 \\
\hline 3 & TAD & 25 & 12 & 48 & 13 & 52 & 248 & 0 & 0 & 0 & 0 & 248 & 1 & 0,004 & 247 & 0,996 \\
\hline 4 & ANN & 14 & 5 & 35 & 9 & 65 & 100 & 3 & 0,03 & 97 & 0,97 & 100 & 6 & 0,06 & 94 & 0,94 \\
\hline 5 & SIND & 21 & 6 & 28 & 15 & 72 & 224 & 0 & 0 & 0 & 0 & 224 & 1 & 0,004 & 223 & 0,996 \\
\hline 6 & NAD & 21 & 15 & 71 & 6 & 29 & 225 & 2 & 0,008 & 223 & 0,992 & 225 & 0 & 0 & 225 & 100 \\
\hline 7 & $\mathbf{A D Z}$ & 19 & 2 & 10 & 17 & 90 & 170 & 15 & 0,088 & 155 & 0,912 & 170 & 1 & 0,005 & 169 & 0,995 \\
\hline 8 & NUR & 25 & 7 & 28 & 18 & 72 & 232 & 1 & 0,004 & 231 & 0,996 & 232 & 1 & 0,004 & 231 & 0,996 \\
\hline 9 & SHA & 23 & 15 & 65 & 8 & 35 & 148 & 11 & 0,074 & 137 & 0,926 & 148 & 1 & 0,006 & 147 & 0,994 \\
\hline 10 & FAL & 13 & 6 & 46 & 7 & 54 & 145 & 3 & 0,020 & 142 & 0,980 & 145 & 0 & 0 & 145 & 100 \\
\hline 11 & PUT & 14 & 7 & 50 & 7 & 50 & 136 & 1 & 0,007 & 135 & 0,993 & 136 & 0 & 0 & 136 & 100 \\
\hline 12 & INN & 16 & 8 & 50 & 8 & 50 & 173 & 3 & 0,017 & 170 & 0,983 & 173 & 0 & 0 & 173 & 100 \\
\hline 13 & $\mathbf{K R I}$ & 26 & 10 & 38 & 16 & 52 & 148 & 11 & 0,074 & 137 & 0,926 & 148 & 1 & 0,006 & 147 & 0,994 \\
\hline 14 & ALI & 11 & 5 & 45 & 6 & 55 & 153 & 1 & 0,006 & 252 & 0,994 & 153 & 0 & 0 & 153 & 100 \\
\hline 15 & DES & 16 & 4 & 25 & 12 & 75 & 133 & 1 & 0,007 & 132 & 0,993 & 133 & 0 & 0 & 133 & 100 \\
\hline 16 & NAB & 26 & 1 & 4 & 25 & 96 & 227 & 2 & 0,008 & 225 & 0,992 & 227 & 1 & 0,004 & 226 & 0,996 \\
\hline 17 & AND & 23 & 4 & 17 & 19 & 83 & 249 & 9 & 0,036 & 240 & 0,064 & 249 & 0 & 0 & 249 & 100 \\
\hline 18 & AXI & 30 & 12 & 40 & 18 & 60 & 263 & 4 & 0,015 & 259 & 0,085 & 263 & 7 & 0,027 & 256 & 0,97 \\
\hline 19 & NOV & 19 & 13 & 68 & 6 & 32 & 221 & 2 & 0,009 & 219 & 0,991 & 221 & 0 & 0 & 221 & 100 \\
\hline 20 & RAH & 10 & 1 & 10 & 9 & 90 & 124 & 2 & 0,016 & 122 & 0,984 & 124 & 1 & 0,008 & 123 & 0,992 \\
\hline 21 & ADJ & 15 & 12 & 80 & 3 & 20 & 176 & 1 & 0,005 & 175 & 0,995 & 176 & 0 & 0 & 176 & 100 \\
\hline 22 & MEY & 36 & 8 & 22 & 28 & 78 & 311 & 4 & 0,012 & 307 & 0,988 & 311 & 0 & 0 & 311 & 100 \\
\hline 23 & ADI & 32 & 2 & 6 & 30 & 94 & 269 & 4 & 0,014 & 265 & 0,986 & 269 & 0 & 0 & 269 & 100 \\
\hline \multirow[t]{3}{*}{24} & ASY & 30 & 7 & 23 & 23 & 77 & 311 & 4 & 0,012 & 307 & 0,988 & 311 & 0 & 0 & 311 & 100 \\
\hline & TO & 534 & 194 & 901 & 340 & 1488 & 5057 & 92 & 0,488 & 4593 & 19,71 & 5057 & 22 & 0,132 & 5035 & 1310,9 \\
\hline & AV & 22 & 8,08 & 37,5 & 14,2 & 62,5 & 210,70 & 3,83 & 0,020 & 191,38 & 0,82 & 210,70 & $\begin{array}{l}0,9 \\
2\end{array}$ & 0,006 & 209,79 & 54,62 \\
\hline
\end{tabular}


In table 1,the total number of T-units produced by students is 534 and the average is $22 \mathrm{~T}$-units, where the lowes Tunit is 10 and the hghest is 36 . The incorrect grammar T-units is $194(37,5 \%)$. Therefore, it can be concluded that language accruracy on grammar is considered low. While the total number of incorrect vocabulary is 92 with the average is $3,8(0,02 \%)$, and the total incorrect spelling is 22 with the average is $1,8(0,01 \%)$. It can be infered that the accuracy of vocabulary and spelling is high.

2.The Effectiveness of teacher's indirect corrective feedback.

The drafts produced by the students were given the codes for incorrect linguistics ; Gr (grammar), Vc (Vocabulary), Sp (spelling). The result can be seen in table 2a.

Table 2a. The Effectiveness of teacher's indirect corrective feedback on grammar accuracy.

\begin{tabular}{|c|c|c|c|c|c|c|c|c|c|}
\hline \multirow[t]{2}{*}{ No } & \multirow[t]{2}{*}{ Code } & \multicolumn{4}{|c|}{ Grammar/T-unit } & \multirow[b]{2}{*}{$\%$} & \multirow[b]{2}{*}{ Conect } & \multirow[b]{2}{*}{ Not Corected } & \multirow[b]{2}{*}{$\%$} \\
\hline & & Tot & Incorrect & $\%$ & corrected & & & & \\
\hline 1 & AIS & 34 & 11 & 32 & 7 & 64 & 7 & 4 & 36 \\
\hline 2 & DBD & 35 & 21 & 60 & 18 & 86 & 18 & 3 & 14 \\
\hline 3 & TAD & 25 & 12 & 48 & 5 & 41 & 5 & 7 & 59 \\
\hline 4 & ANN & 14 & 5 & 35 & 1 & 20 & 1 & 4 & 80 \\
\hline 5 & SIND & 21 & 6 & 28 & 4 & 67 & 4 & 2 & 33 \\
\hline 6 & NAD & 21 & 15 & 71 & 2 & 13 & 2 & 13 & 87 \\
\hline 7 & ADZ & 19 & 2 & 10 & 2 & 100 & 2 & 0 & 0 \\
\hline 8 & NUR & 25 & 7 & 28 & 5 & 71 & 5 & 2 & 29 \\
\hline 9 & SHA & 23 & 15 & 65 & 8 & 53 & 8 & 7 & 47 \\
\hline 10 & FAL & 13 & 6 & 46 & 3 & 50 & 3 & 3 & 50 \\
\hline 11 & PUT & 14 & 7 & 50 & 4 & 57 & 4 & 3 & 43 \\
\hline 12 & LIN & 16 & 8 & 50 & 4 & 50 & 4 & 4 & 50 \\
\hline 13 & KRI & 26 & 10 & 38 & 4 & 40 & 4 & 6 & 60 \\
\hline 14 & AUI & 11 & 5 & 45 & 2 & 40 & 2 & 3 & 60 \\
\hline 15 & DES & 16 & 4 & 25 & 2 & 50 & 2 & 2 & 50 \\
\hline 16 & NAB & 26 & 1 & 4 & 0 & 0 & 0 & 1 & 100 \\
\hline 17 & AND & 23 & 4 & 17 & 2 & 50 & 2 & 2 & 50 \\
\hline 18 & AXI & 30 & 12 & 40 & 4 & 33 & 4 & 8 & 67 \\
\hline 19 & NOV & 19 & 13 & 68 & 3 & 23 & 3 & 10 & 77 \\
\hline 20 & RAH & 10 & 6 & 60 & 2 & 33 & 4 & 2 & 33 \\
\hline 21 & ADJ & 15 & 12 & 80 & 3 & 25 & 3 & 9 & 75 \\
\hline 22 & MEY & 36 & 8 & 22 & 5 & 63 & 5 & 3 & 37 \\
\hline 23 & ADI & 32 & 2 & 6 & 2 & 100 & 2 & 0 & 0 \\
\hline \multirow[t]{3}{*}{24} & Asy & 30 & 7 & 23 & 6 & 86 & 6 & 1 & 14 \\
\hline & Tot & - & 194 & 901 & 96 & 1180 & & & \\
\hline & AV & & 15,5 & 72,1 & 7,7 & 94,4 & & & \\
\hline
\end{tabular}

Based on table 2, it can be seen that 96 out of 194 incorrect grammar were corrected (49\%) by 23 students (96\%) and all of them are grammatically correct. The students did not correct all the ungrammatical sentences because the teacher reminded them not to correct those they are indoubt. Only 1 student (4\%) did not correct hers.

Table 2b.The Effectiveness of teacher's indirect corrective feedback on vocabulary and spelling.

\begin{tabular}{|l|l|l|l|l|l|l|l|l|l|l|l|l|l|l|l|}
\hline No & Cod & \multicolumn{10}{|l|}{ Vocabulary } & \multicolumn{10}{l|}{ Spelling } \\
\hline & & Tot & Inc & $\%$ & SIf & $\%$ & Cor & $\%$ & Inc & $\%$ & Slf & $\%$ & Cor & $\%$ \\
\hline 1 & AIS & 387 & 2 & 0,005 & 2 & 100 & 2 & 100 & 0 & 0 & 0 & 100 & 0 & 100 \\
\hline 2 & DED & 284 & 6 & 0,02 & 6 & 100 & 6 & 100 & 1 & $\begin{array}{l}0,00 \\
4\end{array}$ & 1 & 100 & 1 & 100 \\
\hline 3 & TAD & 248 & 0 & 0 & 0 & 100 & 0 & 100 & 1 & $\begin{array}{l}0,00 \\
4\end{array}$ & 1 & 100 & 1 & 100 \\
\hline 4 & AN & 100 & 3 & 0,03 & 3 & 100 & 3 & 100 & 6 & 0,06 & 6 & 100 & 6 & 100 \\
\hline 5 & SIN & 224 & 0 & 0 & 0 & 100 & 0 & 100 & 1 & $\begin{array}{l}0,00 \\
4\end{array}$ & 1 & 100 & 1 & 100 \\
\hline 6 & NA & 225 & 2 & 0,008 & 2 & 100 & 2 & 100 & 0 & 0 & 0 & 100 & 0 & 100 \\
\hline 7 & ADZ & 170 & 15 & 0,088 & 15 & 100 & 15 & 100 & 1 & $\begin{array}{l}0,00 \\
5\end{array}$ & 1 & 100 & 1 & 100 \\
\hline 8 & NU & 232 & 1 & 0,004 & 1 & 100 & 1 & 100 & 1 & 0,00 & 1 & 100 & 1 & 100 \\
\hline
\end{tabular}




\begin{tabular}{|l|l|l|l|l|l|l|l|l|l|l|l|l|l|l|}
\hline & & & & & & & & & 4 & & & & \\
\hline 9 & SHA & 148 & 11 & 0,074 & 11 & 100 & 11 & 100 & 1 & $\begin{array}{l}0,00 \\
6\end{array}$ & 1 & 100 & 1 & 100 \\
\hline 10 & FAL & 145 & 3 & 0,020 & 3 & 100 & 3 & 100 & 0 & 0 & 0 & 100 & 0 & 100 \\
\hline 11 & PUT & 136 & 1 & 0,007 & 1 & 100 & 1 & 100 & 0 & 0 & 0 & 100 & 0 & 100 \\
\hline 12 & LIN & 173 & 3 & 0,017 & 3 & 100 & 3 & 100 & 0 & 0 & 0 & 100 & 0 & 100 \\
\hline 13 & KRI & 148 & 11 & 0,074 & 11 & 100 & 11 & 100 & 1 & $\begin{array}{l}0,00 \\
6\end{array}$ & 1 & 100 & 1 & 100 \\
\hline 14 & ALI & 153 & 1 & 0,006 & 1 & 100 & 1 & 100 & 0 & 0 & 0 & 100 & 0 & 100 \\
\hline 15 & DES & 133 & 1 & 0,007 & 1 & 100 & 1 & 100 & 0 & 0 & 0 & 100 & 0 & 100 \\
\hline 16 & NA & 227 & 2 & 0,008 & 2 & 100 & 2 & 100 & 1 & 0,00 & 1 & 100 & 1 & 100 \\
\hline 17 & AN & 249 & 9 & 0,036 & 9 & 100 & 9 & 100 & 0 & 0 & 0 & 100 & 0 & 100 \\
\hline 18 & AXI & 263 & 4 & 0,015 & 4 & 100 & 4 & 100 & 7 & $\begin{array}{l}0,02 \\
7\end{array}$ & 7 & 100 & 7 & 100 \\
\hline 19 & NO & 221 & 2 & 0,009 & 2 & 100 & 2 & 100 & 0 & 0 & 0 & 100 & 0 & 100 \\
\hline 20 & RAI & 124 & 2 & 0,016 & 2 & 100 & 2 & 100 & 1 & $\begin{array}{l}0,00 \\
8\end{array}$ & 1 & 100 & 1 & 100 \\
\hline 21 & ADJ & 176 & 1 & 0,005 & 1 & 100 & 1 & 100 & 0 & 0 & 0 & 100 & 0 & 100 \\
\hline 22 & ME & 311 & 4 & 0,012 & 4 & 100 & 4 & 100 & 0 & 0 & 0 & 100 & 0 & 100 \\
\hline 23 & ADI & 269 & 4 & 0,014 & 4 & 100 & 4 & 100 & 0 & 0 & 0 & 100 & 0 & 100 \\
\hline 24 & Asy & 311 & 4 & 0,012 & 4 & 100 & 4 & 100 & 0 & 0 & 0 & 100 & 0 & 100 \\
\hline & Tot & 5057 & 92 & 0,488 & 92 & 240 & 92 & 240 & 22 & 0,13 & 22 & 240 & 22 & 240 \\
& & & & & & 0 & & 0 & & 2 & & 0 & & 0 \\
\hline & AV & 210,7 & 3,8 & 0,020 & 3,83 & 100 & 3,83 & 100 & 0,92 & $\begin{array}{l}0,00 \\
6\end{array}$ & & & & \\
\hline
\end{tabular}

Table $2 \mathrm{~b}$ shows that every one is able to correct his/her own vocabulary and spelling.

3. The Effectiveness of Direct peer corrective feedback during negotiation of meaning.

The students' drafts were given back to each student. In this time each student was instructed to ask for help from his peer(s). After direct peer corrective feedback, the students get better accuracy in grammar, as it is decribed in the following table.

Tabel 3. The Effectiveness of direct peer corrective feedback during negotiation of meaning

\begin{tabular}{|l|l|l|l|l|l|l|l|}
\hline No & Code & Inc & PC & CorPCF & $\%$ & Inc CPCF & $\%$ \\
\hline 1 & AIS & 4 & 4 & 2 & 50 & 2 & 50 \\
\hline 2 & DED & 3 & 3 & 2 & 67 & 1 & 33 \\
\hline 3 & TAD & 7 & 7 & 6 & 86 & 1 & 14 \\
\hline 4 & ANN & 4 & 4 & 4 & 100 & 0 & 0 \\
\hline 5 & SIND & 2 & 2 & 2 & 100 & 0 & 0 \\
\hline 6 & NAD & 13 & 13 & 13 & 100 & 0 & 0 \\
\hline 7 & ADZ & 0 & 0 & 0 & 0 & 0 & 0 \\
\hline 8 & NUR & 2 & 2 & 2 & 100 & 0 & 0 \\
\hline 9 & SHA & 7 & 7 & 6 & 86 & 1 & 14 \\
\hline 10 & FAL & 3 & 3 & 3 & 100 & 0 & 0 \\
\hline 11 & PUT & 3 & 3 & 3 & 100 & 0 & 0 \\
\hline 12 & LIN & 4 & 4 & 4 & 100 & 0 & 0 \\
\hline 13 & KRI & 6 & 6 & 6 & 100 & 0 & 0 \\
\hline 14 & ALI & 3 & 3 & 3 & 100 & 0 & 0 \\
\hline 15 & DES & 2 & 2 & 2 & 100 & 0 & 0 \\
\hline 16 & NAB & 1 & 1 & 1 & 100 & 0 & 0 \\
\hline 17 & AND & 2 & 2 & 2 & 100 & 0 & 0 \\
\hline 18 & AXI & 8 & 8 & 5 & 62 & 3 & 38 \\
\hline
\end{tabular}




\begin{tabular}{|l|l|l|l|l|l|l|l|}
\hline 19 & NOV & 10 & 10 & 6 & 60 & 4 & 40 \\
\hline 20 & RAH & 4 & 4 & 4 & 100 & 0 & 0 \\
\hline 21 & ADJ & 9 & 9 & 9 & 100 & 0 & 0 \\
\hline 22 & MEY & 3 & 0 & 0 & 0 & 0 & 0 \\
\hline 23 & ADI & 0 & 0 & 0 & 0 & 0 & 0 \\
\hline 24 & Asy & 1 & 1 & 1 & 100 & 0 & 0 \\
\hline & T & 99 & $96=97 \%$ & $\begin{array}{l}84 \quad \text { (Correct } \\
\text { feedback)=88\% }\end{array}$ & & $\begin{array}{l}12 \\
\text { (Incorrect } \\
\text { feedback) }\end{array}$ & $\%$ \\
\hline
\end{tabular}

It can be seen in table 3 that there are 22 students (92\%) of the students who have incorrect grammar with the total number of incorrect grammar is 99. After direct peer corrective feedback, only 84 (88\%) T-unit are grammatically correct, while the other $12(12 \%)$ is not correct. Eventhough there are still some ungrammatical sentences ,but at least, direct peer corrective feedback gives contribution to grammar accuracy for each student, except student no 7 and no 23.

\section{Students' Perception After the Learning Process}

The 24 students were asked to answer the 6 main questions related to the 3 categories of perception (level of difficulty, degrees of stress, and motivation) followed by their reasons. In order to avoid misunderstanding and to make the students express their answer easily, the open-ended questions were written in Indonesian language. Then, students' responses related to their reasons were grouped and tabulated based on the catagory; positive, negative or the combination of the two. Below is the result.

Table 4. Students' Perception After the Learning Process

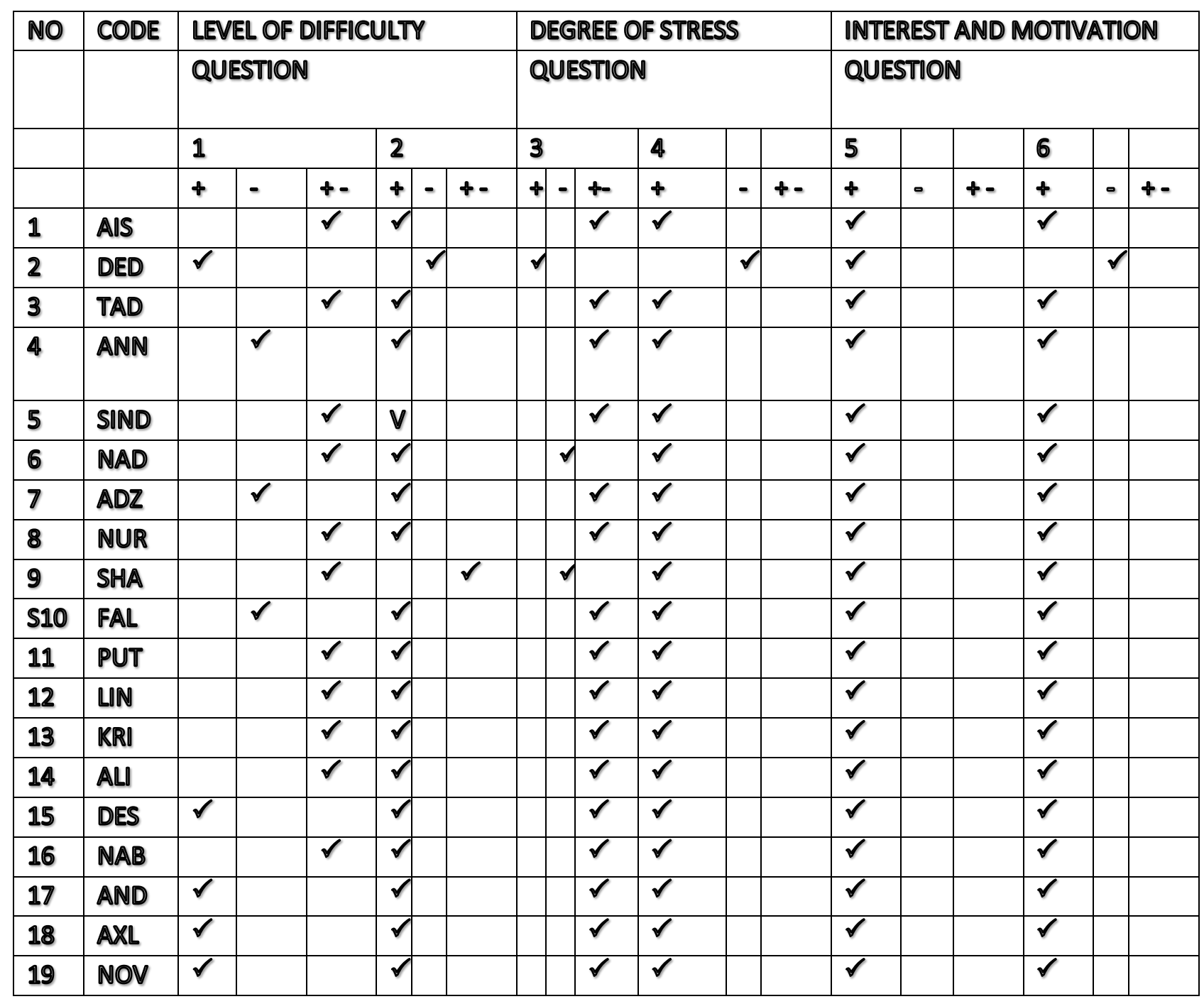




\begin{tabular}{|c|c|c|c|c|c|c|c|c|c|c|c|c|c|c|c|c|c|c|}
\hline 20 & RAH & & & $\checkmark$ & $\checkmark$ & & & & $\checkmark$ & $\checkmark$ & & & $\checkmark$ & & & $\checkmark$ & & \\
\hline 21 & ADJ & $\checkmark$ & & & $\checkmark$ & & & & $\checkmark$ & $\checkmark$ & & & $\checkmark$ & & & $\checkmark$ & & \\
\hline 22 & MEY & & & $\checkmark$ & $\checkmark$ & & & & $\checkmark$ & $\checkmark$ & & & $\checkmark$ & & & $\checkmark$ & & \\
\hline 23 & ADI & & & $\checkmark$ & $\checkmark$ & & & & $\checkmark$ & $\checkmark$ & & & $\checkmark$ & & & $\checkmark$ & & \\
\hline 24 & ASY & & & $\checkmark$ & $\checkmark$ & & & & $\checkmark$ & $\checkmark$ & & & $\checkmark$ & & & $\checkmark$ & & \\
\hline & TOT & 6 & 3 & 15 & $\begin{array}{l}2 \\
2\end{array}$ & $\mathbb{1}$ & 1 & 1 & $\begin{array}{ll}320 \\
\end{array}$ & 23 & $\mathbb{1}$ & 0 & 24 & (1) & 0 & 23 & 1 & 0 \\
\hline & $\%$ & 25 & 13 & 62 & $\begin{array}{l}9 \\
2\end{array}$ & 4 & 4 & 4 & $\begin{array}{ll}1 & 83 \\
3 & \end{array}$ & 96 & 4 & 0 & 100 & (1) & 0 & 96 & 4 & 0 \\
\hline
\end{tabular}

The students' responses to each question are variuos :

a. Level of difficulty. Question 1; 6 (25\%) stated it is easy (+), $3(13 \%)$ is difficult (-) and $15(62 \%)$ easy and difficult (+-), question $2 ; 22$ students $(92 \%)$ stated it is easy $(+), 1(4 \%)$ difficult $(-)$, and $1(4 \%)$ easy and difficult (+-).

b. Degree of stress.Question 3; $1(4 \%)$ stated it is enjoyable (+), $3(13 \%)$ not enjoyable (-), and $20(83 \%)$ enjoyable and not enjoyable (+-). Question $4: 23(96 \%)$ stated it is enjoyable (+), $1(4 \%)$ not enjoyable (-), 0 $(0 \%)$ enjoyable and not enjoyable (+-).

c. Motivation. Question 5; $24(100 \%)$ stated that indirect feedback in form of codes motivate them to write accurate linguistic. Question 6; $23(96 \%)$ stated that peer corrective feedback motivate them to write accurate linguistic. Only one student (4\%) stated that direct peer corrective feedback does not motivate her to think harder about the incorrect grammar.

\section{Discussion}

In this section, the result will be discused based on the findings and relevant theories. The discussion will be based on the research questions provided earlier.

RQ 1. How is writing accuracy of the first year students of the Faculty of English Education Study Program Lampung University?

As it was mentioned earlier, writing accuracy refers to linguistic knowledge, such as knowledge of grammar, vocabulary and spelling (Saadian, H., and Bagheri, M. S.,2014). Having anlyzed the writing draft of the sudents, it was found that, in general, the highest incorrect linguistic is on grammar, followed by vocabulary and spelling (table 1). The students make various kinds of incorrect grammar, for examples; subject-agrement, paralelism, parts of speech, subordinate clause, and subjunctive. However, these incorrect grammar might due to their unawreness (Bourke, 2008). In other words, they did not aware or pay attention to linguistic accuracy. In relation to this, Schmidt (1995) declared that less attention leads to less learning. Therefore, paying attention to linguistic problem, especially on grammar, is badly needed. To have in-debth informatio, it will be discussed below.

RQ 2. How effective is teacher's indirect corrective feedback in enhancing students' writing accuracy?

Eventhough the corrections made by the students, in general, are grammatically correct (96\%), but only 96 out of 194 incorrect grammar were corrected $(49 \%)$ by 23 students. The students did not correct all the ungrammatical sentences because the teacher reminded them not to correct those they are indoubt. Only 1 student (4\%) did not correct hers. She did so because she was not sure the correct one and she thought that hers was already correct.

The indirect corrective feedback (implicit corrective feedback) in form of codes make the students aware of their mistakes. This finding is in line with the idea of Bourke, (2008) that language awareness canchallengelearnerstoaskquestionsandinvolve theminexploring themselvesofhowlanguageworks. In accordance with this, Bitchener, Young and Cameron (2005) stated that feedback in the form of codes are able to improve students' writing in terms of accuracy and Par \& Timperley (2010) stated that corrective feedback provides a writer with information on the quality of the work. The findings of this study indicated that the students were able to correct their incorrect grammar because they pay attention to the indirect feed back in the form of codes and use their prior knowledge about the rules in the target language. In other words, indirect feedback will not work well if the learners do not have prior knowlede about the rules of target language grammar. 
The students only make a few of incorrect vocabulary and spelling. Only one vocab that can not be corrected correctly. She thought that her vocab (word) is already correct, "That is the saying that we often hear'. Contextually the right vocabulary for this sentence is "word" not "saying".This is due to literal translation (Newmark,1988). For spelling, all of them are able to correct them. During this process, some of the students were busy checking the dictionary on their mobile phones.

RQ 3. How effective is negotiation of meaning during the peer corrective feedback.

It can be seen in table 3 that there are 22 students (92\%) who have incorrect grammar with the total number of incorrect grammar is 99 . Only 96 T-units (97\%) out of 99 T-units were corrected by peer(s) and only $84(88 \%)$ T-units are grammatically correct, while the other 12 T-units $(12 \%)$ are not correct. Seeing this result, it can be concluded that direct peer corrective feedback give contribution to grammar accuracy for each student,except student no 7 and no 23. None of students is able to correct their ungrammatical sentences. They all thought that these sentences are already grammaticaly correct; " My mother together with the whole family always have breakfast everymorning, instead of "My mother together with the whole family always has breakfast everymorning". They all thought that the subject of this sentence is in plural form. This is due to their limited knowledge to the rules of target language grammar.

Based on the observation, every one was busy asking for help. Some of them did in pair and some in small group. During direct peer corrective feedback, negotiation of meaning in form of clarification and other correction (Pica, 1985), happened. By providing the correct ones followed by explanation using their native language (direct corrective feedback), makes them understand the correction easily. This finding is contrast with the idea of Tan and Apinya (2017) who declared that indirectWCFwasmoreeffectivethandirectWCF but in line with Lee (2012) who infers peer-correction is better than self-correction.

RQ. 4. How is the students' perception after the learning process?

In relation to students' perception towards learning process, various answers were given to each question. Those who stated that the learning process during the indirect corrective feedback is easy because they can corrrect their incorrect linguistics, and those who stated it is difficult because they think they can not correct their incorrect linguistics.

By analyzing the students' correction during the indirect corrective feedback, those who say it is easy $6(25 \%)$, the emperical data proved that they able to correct theirs. This is in line with Cahyono and Amrina (2016), who discovered that Peer corrective feedback CF is better than self-correction. The other 3 students (13\%) who stated that all their ungrammatical sentences can not be corrected by themselves, thus they percept that it is difficult to understand the materials during the indirect corrective feedback.

Most of students declared that both indirect and direct corrective feedback can motivate them to think harder about the linguistic accuracy. However, they like more direct than indirect corrective feedback, especially in correcting grammar because the peer(s) provided clear expanation using their native llanguage.

\section{Conclussion}

Focused corrective feedback both indirect and direct corrective feedback on linguistic accuracy (grammar, vocabulary, and spelling) can enhance students' writing accuracy.Both of them make the students aware of their linguistics accuracy and enable them to correrct their mistakes. However, indirect corrective feedback will work well only if they have prior linguistic knowledge. In other word, they get stuck if they can not correct their ungrammatical sentences and it makes them stress. While during direct peer corrective feedback in form of expalanation using their native language, makes students feel more enjoyable and get input for his writing quality.By providing corrections on students' writing (work), they can internalize the correction (input), because all the ungrammatical sentences were produced by themselves. It is in line with Swain, and Lapkin. (1995) who stated that the learner can get input through his own output if there is correction from his peer.

\section{Refences}

Ahangari, S., and Barghi, A. H. (2012). Consistency of measured accuracy in grammar knowledge tests and writing: TOEFL PBT. Language testing in asia, (May).

Ahmad, N.A., Azizan, F.L., Rahim, N.F. (2017). Relationship between students' perception toward the teaching and learning methods of mathematics' lecturer and their achievement in pre-university studies. Canadian Center of Science and Education, Vol. 10, No. 11.

Alqahtani, M. (2015). The importance of vocabulary in language learning and how to be taught. International Journal of Teaching and Education, III(3), 21-34. https://doi.org/10.20472/TE.2015.3.3.002

Bae, J. (2001). Cohesion and coherence in children' $s$ written english: Immersion and english-only classes. Regents of the University of California, 12(1), 51-88. 
Bitchener, J, Young, S, and Cameron, D. (2005). The effect of different types of corrective feedback on esl student writing. Journal of Second Language Writing.Volume 14, Issue 3, September 2005, 191-205

Bitchener, J. \& Ferris, D. R (2012).Written corrective feedback in second language acquisition and writing. New York: Routledge. Bitchener \& Ferris, 2012)

Bolton, F. \& D, Snowball (1993). Teaching spelling: A practical resource. Portsmouth.NH: Heinemann.

Bourke, J. 2008. A rough guide to language awareness. Teaching Forum, 1: 12-21.

Brown, H. Douglas. (2001). Teaching by principles an interactive approach to language pedagogy. The United

States of New York: Longman.

Cahyono, B.Y., Amrina, R. (2016). Peer feedback, self-correction, and writing proficiency of indonesian efl students.Arab World English Journal (AWEJ), Volume 7, Number 1, Pp. 178 -193, March 2016

Cook, V. (2010). L2 users and english spelling. Journal of Multilingual and MulticulturalDevelopment, 37-41.

Dakhi, S. (2019). The principles and the teaching of english vocabulary: A Review. Journal of English Teaching, 5(February 2019), 15-25.

Ellis, R. (2009). Corrective feedback and teacher development. L2 Journal, UC Consortium for Language Learning \& Teaching, UC Davis, 1(1), 2-18. L2 Journal,Volume1,2009,pp; 3-18 https://doi.org/10.5811/westjem.2011.5.6700

Farangis, Saeedi. (2013). The effect of negotiation in second langage acquisition. Educational Journal.Publishedonline,November10,2013.(http://www.sciencepublishinggroup.com/j/edu)doi:10.11648/ j.edu.20130206.15.

Flora. (2016). Negotiation of meaning: An analysis of oral communication. Bandar Lampung. AURA.2016.

Flora. (2019). Integrating mind mapping (MM) and three-step-interview (TSI) in enhancing

students' writing process in foreign language setting. International Journal of Language and Linguistics. Volume 6, no.4, Desember 2019.

Flora. 2020. A Modified roundtale technique based on process approach to promote

the students' writing achievements in foreign language setting. International Journal of Education and Practice, Vol. 8, No. 1, pp. 149-157

Hawkey, R. (2006). Teacher and learner perceptions of language learning activity. ELT Journal, 60(July), 242-252. https://doi.org/10.1093/elt/ccl004

Heaton, J. B. (1991). Writing english language tests. New York: Longman.

Hinkel, E. (2011). Handbook of research in second language teaching and learning. Volume II. New York: Routledge.

Jacobs, H., Zinkgraf, S., Wormuth, D., Hartfiel, V., \& Hughey, J. (1981). Testing esl composition: A practical approach. Rowley, MA: Newbury House.

Javed, M., Juan, W. X., and Nazli, S. (2013). A Study of students' assessment in writing skills of the english language. International Journal of Instruction, 6(2).

Ko, J, Schallert D.L, and Walters,K. (2003). Rethinking scaffolding: Examining negotiation of meaning in an esl storrytelling.Tesol Quartely,Vol. 37, No. 2, Summer 2003, pp.303-324.

Kreiner, D. S., Schnakenberg, S. D., Angela, G., Costello, M. J., and Mcclin, A. F. (2014). Effects of spelling errors on the perception of writers. The Journal of General Psychology, (October 2014), 37-41. https://doi.org/10.1080/00221300209602029

Kurzer, Kendon. (2017). Dynamic corrective feedback in developmental multilingual writing classes. TESOL QUARTERLY Vol. 0, No. 0, xxxx2017, pp.1-33.

Lee, C., Cheung, W.K.W., Wong, K.C.K., \& Lee, F.S.L. (2013). Immediate web-based essay cri- tiquing system feedback and teacher follow-up feedback on young second language learners' writings: An experimental study in a Hong Kong secondary school. Computer Assisted Lan- guage Learning, 26(1), 39- 60

Moussa, A ,Yazdani, H, and Mehri, E . (2019). The Effectiveness of learners' preferred and unferred written corrective feedback: A think-aloud study. The Journal of Asia TEFL, vol.16.No.2, Summer 2019, 448- 467.http:dx.doi.org/10.18823/asiatefl.2019.16.2.1.448.

Newmark, P. (1988). A textbook of translation. New York and London. Prentice Hall.

Pica, T and Doughty. (1985). Interactional modification in negotiation of meaning: A comparison of lock step system and group work interaction. In Susan M. Gass and

Carolyn G. Madden (eds). Input in second language acquisition. NewYork : Newbury House Publishers, 1985.

Pica, Teresa. (1994). Review article. Research on negotiation :What does it reveal about second language learning

: Conditions, processes, and outcomes?. Language Learning

44:3, September 1994, pp.493-527.

Polard, L. (2008). A guide to teaching english. Retrieved from

http://books.google.co.jp/books?id=klkIAQAAIAAJ\&amp;q=jalt+nagoya\&amp;dq=jalt+nagoya\&amp;hl=\&amp;c $\mathrm{d}=8 \&$ amp;source $=$ gbs_api 
Saadian, H., and Bagheri, M. S. (2014). The Relationship between grammar and vocabulary knowledge and iranian efl learner's writing performance (TOEFL PBT Essay). International Journal of Language Learning and Applied Linguistics World (IJLLALW), 7(September), 108-123.

Susanto, A. (2017). The teaching of vocabulary: A perspective. Lembaga Layanan Pendidikan Tinggi (L2DIKTI) Wilayah X, (1)2, 182-191.

Sheen, Y. and Ellis, R. (2011). Corrective feedback in language teaching. In Handbook of Research in Second Language Teaching and Learning. New York: Routledge.

Schmidt, R. W. (1995). Consciousness and foreign language learning: A tutorial on the role of attention and awareness in learning. In R. Schmidt (Ed.), Attention and Awareness in ForeignLanguage Learning (pp. 165). Honolulu: University of Hawaii Press.

Swain, M. and S. Lapkin. (1995). Problems in output and the cognitive processes they generate: A step towards second language learning. Applied Linguistics 16:371-391.

Tai, Hsuan-Yu. 2015. Writing development in syntactic complexity, accuracy and fluency in a content and language integrated learning class. International Journal of Language and Linguistics, Vol.2, no.3, Sepetember 2015.

Tan, Kok Eng and Manochphinyo, Apinya. (2017). Improving grammatical accuracy in thai learners' writing: Comparing direct and indirect corrective feedback. The Journal of ASIA TEFL,vol.14, no 3, 430-442.

Tavakoli, P. (2009). Investigating task difficulty: Learners' and teachers' perceptions. International Journal of Applied Linguistics, 19:1, pp. 1-25.

Trabelsi, Soufiane. (2018). Comparing the general foundation programme's english teachers' belief and practices regarding written corrective feedback in an omani elf context. International journal of language and linguistics. Volume 5, no.4, december 2018. 